\title{
FOUNDING FATHERS
}

\section{The Celebration of Champlain and Laval in the}

Streets of Quebec, 1878-1908

The late nineteenth and early twentieth centuries saw an unprecedented wave of public celebration of the past. Throughout the western world, heroes and great events from earlier times were celebrated by staging lavish parades, constructing intricately designed monuments, and mounting theatrical re-enactments of pivotal moments in history. In Quebec, two individuals occupied centre stage in these commemorations: Samuel de Champlain, the founder of Quebec City, and often referred to as the lay father of French-Canadian civilization, and Mgr François de Laval, the first bishop of Quebec, commonly seen as French Canada's religious father. Between 1878 and 1908 these men were fêted in four commemorative mega-events staged in the streets of Quebec City.

Based largely on the archival documents left behind by the lay and ecclesiastical leaders who organized the celebrations of Champlain and Laval, Ronald Rudin's study describes the complicated process of staging these spectacles. The vast array of leaders - lay and clerical, French- and English-speaking - rarely saw eye to eye about either the form or the goal of commemorative celebration. Accordingly, the tens of thousands who came out to view these affairs witnessed events with numerous messages. An examination of the four spectacles, which took place over a period of thirty years, provides an opportunity to view both changes in the nature of commemorative celebrations across the western world and tensions within Canadian society.

RONALD RUDIN is a professor of history at Concordia University and is the author of Making History in Twentieth Century Quebec (1997). 
This page intentionally left blank 


\section{FOUNDING FATHERS}

The Celebration of

Champlain and Laval

in the Streets of Quebec,

I $878-1908$

Ronald Rudin

UNIVERSITY OF TORONTO PRESS

Toronto Buffalo London 
www.utppublishing.com

(C) University of Toronto Press Incorporated 2003

Toronto Buffalo London

Printed in Canada

ISBN 0-8020-3645-7 (cloth)

ISBN 0-8020-8479-6 (paper)

()

Printed on acid-free paper

\section{National Library of Canada Cataloguing in Publication}

\section{Rudin, Ronald}

Founding fathers : the celebration of Champlain and Laval in the streets of Quebec, 1878-1908 / Ronald Rudin.

Includes bibliographical references and index. ISBN 0-8020-3645-7 (bound) ISBN 0-8020-8479-6 (pbk.)

1. Québec (Quebec) - Centennial celebrations, etc. 2. Champlain, Samuel de, 1567-1635 - Anniversaries, etc. 3. Laval, François de Montmorency, 1623-1708-Anniversaries, etc. 4. Québec (Quebec) - History. I. Title.

FC2946.36.R83 $2003 \quad 971.4^{\prime} 47103 \quad$ C2003-900022-2 F1054.5.Q3R83 2003

This book has been published with the help of a grant from the Humanities and Social Sciences Federation of Canada, using funds provided by the Social Sciences and Humanities Research Council of Canada.

University of Toronto Press acknowledges the financial assistance to its publishing program of the Canada Council for the Arts and the Ontario Arts Council.

University of Toronto Press acknowledges the financial support for its publishing activities of the Government of Canada through the Book Publishing Industry Development Program (BPIDP). 
To the memory of two founding fathers:

\section{ABE RUDIN}

(1919-1998)

\section{HAROLD WOLL}

(1910-2001) 
This page intentionally left blank 